\author{
Visión Electrónica \\ Más que un estado sólido \\ https://doi.org/10.14483/issn.2248-4728
}

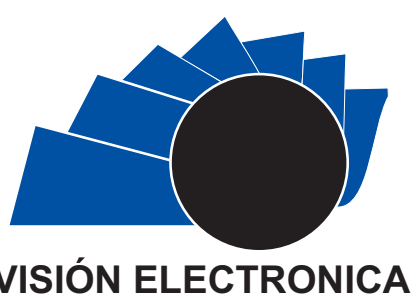

A Research Vision

UNIVERSIDAD DISTRITAL

FRANCISCO JOSÉ DE CALDAS

\title{
Lactate in capillary blood after a vertical jump
}

\section{Lactato en sangre capilar después de un salto vertical}

Eider Mauricio Arce-Rodríguez', Mayerlin Dayana Valdivieso-Cerón ${ }^{2}$

\section{INFORMACIÓN DEL ARTICULO}

Historia del articulo

Enviado: 03/03/2018

Recibido: 21/04/2018

Aceptado: 14/05/2018

\section{Keywords:}

Athletes,

Carbohydrates,

Lactate,

Short stimulus.

\section{Palabras clave: \\ Atletas, \\ Carbohidratos, \\ Lactato, \\ Estímulo corto.}

\begin{abstract}
This study seeks to determine if variations of carbohydrate intake, before the execution of a short stimulus, may have an impact on lactate concentrations in the athlete's body. Conducting a test with a short stimulus (Abalakov's jump), 12 athletes were evaluated (elite category), in 4 days of interleaved testing: on the first day they were provided with a special diet (low in carbohydrates), the second day they were asked to perform the test, on the third day they changed the diet (high in carbohydrates), and on the fourth day the test was again performed to compare both moments. For the tests, capillary blood should be extracted from the ear lobe, being the athlete at rest, the subject performs a vertical jump without impulse and followed by this, samples are taken after 1, 3, 5 and 7 minutes. The procedure is the same for both tests, as a result it is observed that in both moments, the type of diet low or high in carbohydrates does not influence the concentration of lactate in the blood capillary of the athletes.
\end{abstract}

\section{RESUMEN:}

Este estudio busca determinar si las variaciones de la ingesta de carbohidratos, antes de la ejecución de un estímulo corto, pueden tener impacto en las concentraciones de lactato en el cuerpo del atleta. Realizando una prueba con un estímulo corto (salto de Abalakov), se evaluaron 12 atletas (categoría élite), en 4 días de pruebas intercaladas: el primer día se les proporcionó una dieta especial (baja en carbohidratos), el segundo día realizaron la prueba, al tercer día cambiaron la dieta (alta en carbohidratos), y en el cuarto día se realizó nuevamente la prueba para comparar ambos momentos. Para las pruebas, la sangre capilar debe extraerse del lóbulo de la oreja, estando el atleta en reposo, el sujeto realiza un salto vertical sin impulso y seguido de esto, las muestras se toman después de 1, 3, 5 y 7 minutos. El procedimiento es el mismo para ambas pruebas, como resultado se observa que en los dos momentos, el tipo de dieta baja o alta en carbohidratos no influye en la concentración de lactato en la sangre capilar de los atletas.

\footnotetext{
${ }^{1}$ Professional sport, University: National school of sport, Colombia. Specialist in physical activity, University: National school of sport, Colombia. Current position: Physical trainer Club Atlas CP, Monitor Secretary of Sport and Recreation and personal trainer. E-mail: eider.arce@endeporte.edu.co. ORCID: https://orcid.org/0000-0002-1578-3680.

${ }^{2}$ Professional sport, University: National school of sport, Colombia. Current position: Sports trainer Secretary of Sport and Recreation, Athletic trainer A \& D Heatlh \& Wellness. E-mail: mayerlin.valdivieso@endeporte.edu.co. ORCID: https://orcid.org/0000-0001-9224-7155. 


\section{Introduction}

According to the energy continuum, the development and length of the activities are determined, at the same time by an energy substrate, which is this order, first, the use of phosphocreatine or the use of phosphine, glycogen, fatty acids and proteins, all of these substrates with a time of use. Within the energy continuum and the length of the efforts, there is an aerobic and anaerobic metabolism; within the anaerobic, it is subdivided in two, lactic anaerobic and alactic anaerobic. According to some theories the alactic anaerobic metabolic and the utilization of the phosphgenes, is reflected in a lasting activity equal or inferior to 4 seconds, which means that there should not be an increase of the lactate with the perform of the stimulus of the vertical jump, which has a duration approximately of 1 second.

The predominance according to the two types of metabolism mentioned before, for the athlete performing the vertical jump, is the anaerobic metabolism, which is the metabolism that does not use oxygen and it has the characteristic of using carbohydrates in the form of glucose and glycogen to produce energy immediately.

The aim is to observe the behavior of capillary lactate concentrations after the execution of a vertical jump, taking the carbohydrate intake as a variant.

A comparison of results is made in the group that consumes low carbohydrate intake prior to the jump, and also in the group that consumes a high carbohydrate intake, in that way it will be possible to show if capillary lactate concentrations are equal or different. In order for the results to be valid and with good support, a menu must be controlled and it must be provided to the athletes 24 hours before sampling.

Based on the results, it will be possible to contrast with theories, scientific articles published in magazines and books, relative to the subject, that mostly hold that there should not be an increase in lactate concentrations. This investigation will serve to observe if according to the energy continuum all the conception of the energetic substrata is an absolute truth. Besides it will be possible to observe if a high or low carbohydrate intake, previous to a short and powerful stimulus, as it is the jump, generates alterations in lactate concentrations in the body.

In addition to this, this work is done in order to seek an improvement in the athletic performance of athletes. Their health, their state of mind, their nutrition, and how they can achieve better results in training and skills. Through the implementation of a diet or a menu that contains high concentrations of carbohydrates
Valle del Cauca's athletics could have a marked improvement and a better preparation to increase optimal conditions to compete.

\section{Experimental design}

It is intended to observe the behavior of lactate from a stimulus, taking into account a previous intake of carbohydrates, taking as sample 12 athletes of the modality of 100 meters Valle's team, senior category, to which a nutritional base plan is generated that will have a low carbohydrate intake for the performance of the test or the stimulus. After this, with the same group, a high carbohydrate intake will be monitored and there will be two days of evaluations, each with a 24-hour control of the daily diet, ensuring that the group is homogeneous and that the largest possible variables can be controlled. The procedure to be performed is to take a lactate sample at rest with the BIOSEN lactate meter, then the stimulus is executed and the second lactate sample is taken, followed by the incoming doses, being taken at one minute, at 3 minutes, at 5 minutes and 7 minutes.

\section{Methods}

The deductive method is used since it is taking into account a generality that is blood lactate and dietary intake, these two are minutiae such as the importance of carbohydrates in a diet to lower lactate concentrations.

In addition to this, the statistical method is used, one part is done with descriptive statistics and the other with inferential statistics supported by the SPSS.11.5 program (Statistical Package for the Social Sciences or Statistical Product and Service Solutions).

\section{Design}

There are 4 days of tests. On day $1^{\text {st }}$ the 12 subjects are supplied with a food menu from breakfast to dinner, the first diet is isocaloric, containing $2500 \mathrm{kcal}$ of which $50 \%$ are carbohydrates, this is the low carb diet. On day $2^{\text {nd }}$ the first test is performed, following the protocol below, capillary blood samples are taken from the lobe of the right ear to each athlete at rest, followed by this, the execution of the stimulus is done (Abalakov's jump). When the athletes are seated, samples are taken at the minute, at 3 minutes, at 5 minutes and at 7 minutes. After the execution of the stimulus, the samples are stored in the refrigerator. By having all the samples of the 12 athletes, the amount of lactate is measured in the BIOSEN lactate meter. Afterwards, the data is recorded in a database in Excel.

On day $3^{\text {rd }}$ athletes are given a diet, also isocaloric, of 
$2500 \mathrm{kcal}$ of which $65 \%$ of it are carbohydrates, this intake is high in carbohydrates. On day $4^{\text {th }}$ the second test is performed with the same protocol as the previous test and finally the data is saved in the first Excel sheet.

Once the data is collected, the descriptive statistics are handled and then the inferential statistics are processed where the information is processed through the SPSS.11.5 program (Statistical Package for the Social Sciences or Statistical Product and Service Solutions). A revision to the normality conditions is made by the Shapiro Will test. In the same way, a homoscedasticity test is used and finally the nonparametric Mann Whitney test is used for independent samples.

\section{Results}

From Figures 1 and 2 it can be observed that the data are related to each other. Since the result at a later time depends on the previous moment, the trends are conserved despite the existence of the differences, which is why we go to the calculation of averages and standard deviations for each moment of time and type of diet

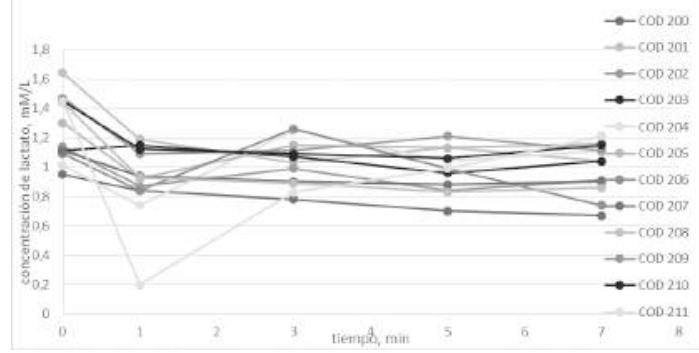

Figure 1. Lactate concentrations in the 12 athletes, with a previous diet low in carbohydrates. Source: own.

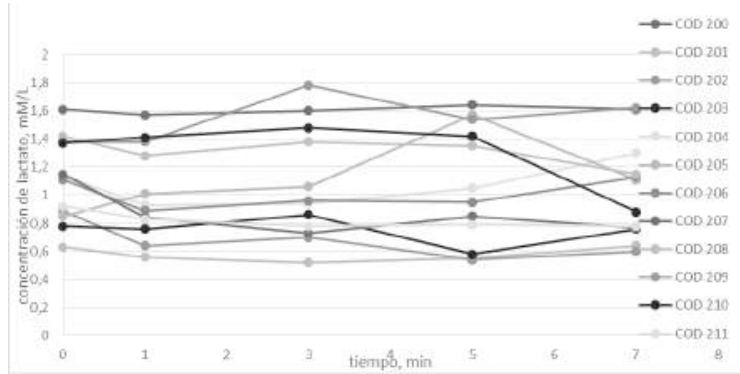

Figure 2. Lactate concentrations in the 12 athletes, with a previous diet high in carbohydrates. Source: own.

From the results, it is possible to see some unusual behaviors of a low carbohydrate intake given on day $1^{\text {st }}$, the results of the tests give us a point of significance in the relationship with rest $(0)$ and the first minute after the execution of the jump, rest (0) with 3 minutes later, rest (0) with 5 minutes and rest (0) with 7 minutes, where in these values there is significant positive and negative difference, where lactate levels increase and decrease but always different to the initial value, Table 1 . For the purpose of verifying whether these changes are statistically significant, we proceed to verify the conditions of normality through inferential analysis.

Figure 3, shows the values of lactate average in capillary blood with high and low intake at all times.

\begin{tabular}{|c|c|c|c|c|c|}
\hline DIETS & $\min 0$ & $\min 1$ & $\min 3$ & $\min 5$ & $\min 7$ \\
\hline $\begin{array}{c}\text { Diet 1 low in } \\
\text { CHOS }\end{array}$ & $1,23 \pm 0,22$ & $0,90 \pm 0,26$ & $1,03 \pm 0,16$ & $0,98 \pm 0,15$ & $0,99 \pm 0,17$ \\
\hline $\begin{array}{c}\text { Diet 2 high in } \\
\text { CHOS }\end{array}$ & $1,10 \pm 0,30$ & $1,01 \pm 0,33$ & $1,07 \pm 0,40$ & $1,07 \pm 0,42$ & $1,03 \pm 0,35$ \\
\hline
\end{tabular}

Table 1. Averages and their respective deviations of lactate concentrations in the blood throughout the observation time. Source: from the SPSS.11.5 program (Statistical Package for the Social Sciences or Statistical Product and Service Solutions). Source: own.

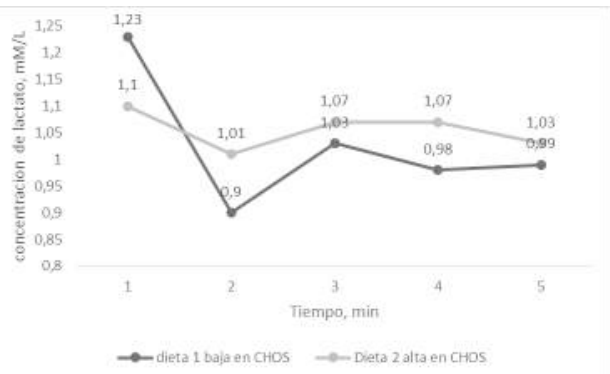

Figure 3. Concentrations of capillary blood lactate averages between rest (0) and 7 minutes after the execution of the stimulus. Source: own.

The Shapiro Wilk test is performed to determine the conditions of normality of the data and for this the following hypotheses are proposed: H1: the dependent variable, which is the concentration of lactate, is normally distributed. H2: the dependent variable, which is the concentration of lactate, is not normally distributed.

Result: the observation of the results shows that none of the variables are important, and most of them present a value above 0.05 , a single value presents a different behavior, but since it is only a data, it is relevant, which is why concludes that there are no significant differences in any of the moments. From this the null hypothesis is accepted, since the data are normally distributed with both diets, for which we proceed to verify if the variances are homogeneous to determine whether a parametric or non-parametric test is used.

Following this, the homoscedasticity test for a 
dependent variable is presented which allows to verify if the variances are homogeneous by Levene's test. Where two hypotheses are proposed: H1: the samples have equal variances. H2: the samples have unequal variances.

Result: due to the three of the p-values thrown are less than 0.05 , the alternative hypothesis is rejected. From this point of view, with $95 \%$ confidence and $5 \%$ significance, it is affirm that there is no statistical evidence of homogeneity of variables.

Finally, the nonparametric test of Mann Withtney is carried out for independent samples, taking into account that their variances are not homogeneous. From this, 2 hypotheses are proposed: $\mathbf{H} \mathbf{1}$ : There is no significant difference between the groups compared according to the type of diet. H2: there is a significant difference between the groups compared according to the type of diet. The groups compared are the resting times after the execution of the vertical jump. Where the moment $\mathrm{O}$ is equal to the rest $(0)$, moment 1 is equal to the first minute after the execution of the stimulus and so on.

Result: The p-values of $\mathrm{U}$ in Mann Whitney thrown, they exceed 0.05 and for this reason the null hypothesis is accepted. From this perspective it is conclude that there is statistical evidence of $95 \%$ confidence and $5 \%$ significance, that the type of diet does not influence the concentration of lactate in the blood capillary of the athletes.

\section{Discussion}

Regarding the data of moment 2 (high carbohydrate intake), only a significant difference is founded in the resting samples $(0)$ with the first minute after the test. The minutes 3, 5 and 7 are stabilized and no significant differences are found, Juel [1] proposes the activation of the monocarboxylic transporters and the recruitment of specific fibers of the stimulus, in which in this case the recruitment is of fast fibers and from which the MCT1 and MCT4 can be activated for the lactate removal being the MCT1 a high affinity lactate transporter, predominantly present in oxidative fibers, whereas MCT4 is a low affinity lactate transporter and facilitating the extraction of lactate outside muscle cells with a high concentration.

MCT1 facilitates the uptake of lactate in muscle cells with low levels of lactate, this removal can be observed, according to the results obtained and attributed to the activation of these and according to what is supported by Brooks [2] MCTs have functional variants or isoforms that, by virtue of their individual kinetics and their specialized expression by type of cell, they move the lactate in one direction or another of the membrane, which allow the transport of lactate depending on the muscles during exercise.

Similarly, to López [3], he talks about the metabolism of carbohydrates, which allow energy to be obtained both in aerobic conditions and in anaerobic conditions, it is the only substrate that the cell is able to use to obtain energy with a high amount of energy. Oxygen or with a deficit of it. The process by which cells obtain energy from glucose, in anaerobic conditions is called glycolysis, the final product of this process within the cell is the production of lactate.

Chamari [4] is taken as a fundamental basis to perform the test protocol where the results were expected to be similar, however it is evident that the place of extraction of the lactate samples has a high incidence in the concentrations of the same, this it is a very important determinant, since the author makes the extractions in venous blood and in this, there is a progressive increase in lactate concentrations with a directly proportional increase, as time passes, after the execution of the jump, the Lactate levels increase significantly. In contrast, the place of extraction was in capillary blood, samples taken from the lobe of the right ear of each subject.

Sánchez [5] proposes a study on the influence of the place of extraction of lactate, where a simultaneous measurement of lactate was made in finger and ear, an incremental effort test was performed in kayakergometro where the conclusion was reached according to the evidenced results that higher concentrations of lactate in the finger pulp than in the lobe of the ear.

Similarly, Aguado [6] performed an analysis comparing lactate levels after simultaneous extraction of finger and vein from cubes of the same arm during an incremental test of a cyclo-ergometer, in this study the results obtained showed higher initial and variable concentrations during the first three stages that those samples obtained in the vein, however these differences disappeared in the fourth stage when the skin flow increases to eliminate the heat.

Venura [7], in which his study consisted of verifying if there was a difference in the place of finger-to-ear sampling since these could be essential determinants when planning and evaluating an athletic training program, it was evidenced that Significant changes in the place of extraction of the sample. Higher levels were always found in finger than in ear, this leads to consider that in the work done there are variants that should have been taken into account and these could have beenan explanation of why they did not obtain similar results to the study carried out by Chamari [4]. 


\section{References}

[1] C. Juel, "Lactate transport in skeletal muscle role and regulation of the monocarboxylate transporter", The Journal of Physiology, vol. 517, no. 3, 2004, pp. $633-642$. https://doi.org/10.1111/j.14697793.1999.0633s.x.

[2] G. A. Brooks, "Intra and extra cellular lactate shuttles", Medicine and sciences in sports and exercise, vol. 32, no. 4, 2000, pp. 790-799. https://doi.org/10.1097/00005768200004000-00011.

[3] J. López, "Fisiología del ejercicio, sistemas energéticos", Madrid, España: Editorial Panamericana, 2008, pp. 185-190.

[4] K. Chamari, "Venous blood lactate increase after vertical jumping in volleyball", European Journal of Applied Physiology, vol. 85, no. 2, $2001, \quad$ p p. $\quad 191-194$. https://doi.org/10.1007/s004210100415.

[5] A. Sánchez, "Influencia del lugar de extracción en la determinación de los niveles de lactato durante una prueba de esfuerzo incremental", Revista Andaluza de medicina del deporte, vol. 1, no. 2, 2008, pp. 57-60.

[6] R. Aguado, "Influencia del lugar de muestreo (dedo-vena) en los resultados de un test de lactato", 2003. [Online]. Available at: https://cienciadeporte.eweb.unex.es/congres o/00\%20cac/RD/FI/ 1lactato.pdf.

[7] J. L. Venura, "Differences between lactate concentration of simples from ear lobe and fingertip", European Journal of Applied Physiology, vol. 55, no. 4, 1999, pp. 333-339. 